\title{
Prinsip Keadilan dalam Kewajiban Pajak dan Zakat Menurut Yusuf Qardhawi
}

\author{
Dina Yustisi Yurista* \\ Universitas Wahid Hasyim (UNWAHAS), Semarang \\ Email: dienay1989@gmail.com
}

\begin{abstract}
As Muslim, we ought to follow the Islamic law and doing all command in Islam. For instance, paying what we have with predefined size to the rightful people which is referred as zakah. Beside, as Indonesian, we have the obligation to pay some our treasure to the country which is called by tax. The zakah system in Islam is the most important financial system to build the balance between people, while the state tax system enforces a good financial in order to meet the defense and provision of public service. With the public awareness in the implementation of zakah and taxes at the same time, therefore it will be needed the justice to avoid the fraud in the practice both of them. The objective of this research is to know and describe the principles of justice between tax and zakah from Yusuf Qardhawi Perspective. This research is literature study with a historical approach. After the primer and secondary data are collected, this study use inductive and deductive method, also content analysis description method for taking the conclusion. This research concludes the that Yusuf Qardhawi permits the obligation between zakah and tax at the same time with some terms of tax which are the tax is really needed, fair distribution, the taxes are used for the benefit of the ummah and the agreement from experts and scholars in this case. Therefore, the principles of justice between tax and zakah according to Yusuf Qardhawi are justice, certainty, feasibility, and economics.
\end{abstract}

Keywords: Taxation, Zakah, Yusuf Qardhawi.

* Dosen Luar Biasa Jurusan Ekonomi Islam, Fakultas Ekonomi \& Bisnis UNWAHAS, Semarang. 


\section{Abstrak}

Dalam Islam kita harus mematuhi segala hukum yang berlaku, semua perintah dalam agama harus dijalankan tak terkecuali dengan kita mengeluarkan harta yang kita miliki dengan ukuran yang telah ditentukan kepada orang-orang yang berhak atau lebih kita kenal dengan istilah Zakat. DI luar itu, kita sebagai warga negara Indonesia juga memiliki kewajiban untuk membayar uang kepada negara atau yang kita sebut pajak. Sistem zakat dalam Islam adalah sistem keuangan yang paling penting untuk menciptakan keseimbangan antara masyarakat, sedangkan sistem perpajakan negara untuk menegakkan jumlah keuangan yang baik agar dapat memenuhi pertahanan dan ketentuan pelayanan masyarakat. Dengan adanya kesadaran masyarakat dalam pelaksanaan pajak dan zakat dalam satu waktu, maka dibutuhkan keadilan dalam pelaksanaan keduanya untuk menghindari kecurangan. Tujuan dari penelitian ini adalah untuk mengetahui dan membahas pemikiran-pemikiran Yusuf Qardhawi tentang prinsip keadilan dalam kewajiban pajak dan zakat. Penelitian ini merupakan kajian literature, dengan pendekatan historis. Setelah data primer dan sekunder terkumpul, penelitian ini menggunakan metode induktif dan deduktif, kemudian tehnik analisa deskriptif sebagai pengambilan suatu kesimpulan. Penelitian ini menyimpulkan bahwa Yusuf Qardhawi membolehkan kewajiban pajak selain zakat, akan tetapi pajak tersebut harus benar-benar dibutuhkan dan tidak ada sumber lain, pembagian beban pajak yang adil, pajak digunakan untuk kepentingan umat, dan persetujuan para ahli dan cendikia. Adapun prinsip keadilan dalam kewajiban pajak dan zakat menurut Yusuf Qardhawi meliputi keadilan, kepastian, kelayakan dan ekonomis.

Kata Kunci: Zakat, Pajak, Prinsip Keadilan.

\section{Pendahuluan}

$G$ slam sebagai al-Din memiliki seperangkat aturan atau syariat, yang mengatur tata cara hubungan antara manusia dengan al-Khaliq (ibadah) dan hubungan antar sesama manusia (mu'amalah), dalam seluruh aspek, baik aspek ekonomi, politik, sosial budaya, pertahanan dan keamanan negara, teknologi, dan lain-lain. 
Dalam bidang ekonomi (majal Iqtishadi), Al-Qur'an dan Hadits mengatur bagaimana tata cara individu dan negara memperoleh pendapatan (mawarid), sehingga terpenuhi berbagai kebutuhan seluruh umat manusia (kolektif), baik kebutuhan pribadi maupun kebutuhan negara (daulah). Terpenuhinya berbagai kebutuhan itu sangat diperlukan untuk mengabdi secara sempurna kepada Allah SWT. ${ }^{1}$

Zakat merupakan salah satu pilar penting dalam Islam, dan karenanya menjadi bagian tak terpisahkan dari kehidupan umat Islam, tak terkecuali di Indonesia. Namun dalam praktek, zakat yang bertujuan mulia tersebut masih dirasa jauh dari yang diharapkan dan masih "gagal" menjembatani jarak si kaya dengan si miskin dan juga untuk mengangkat kaum lemah dan yang diperlemah (duafa' waal-mustad'afin). Barngkali hal ini menjadi cukup alasan jika persoalan zakat selalu mencuat ke permukaan dan menjadi bahan kajian berbagai lapisan masyarakat. $^{2}$

Pada saat pertama kali Umar ra membentuk diwan dalam pemerintahan Islam, beliau tidak memberikan pajak selain zakat. Zakat merupakan satu-satunya kewajiban harta kekayaan yang harus dibayarkan warga. Sebuah pemberian (pajak) yang diwajibkan negara untuk menjaga kelangsungan kehidupan dan mencukupi segala kebutuhan, ketentuan ini sudah ada jauh sebelum sistem kapitalis melakukannya.. Sebuah kewajiban yang diperuntukkan untuk menopang para pengangguran dan orang-orang yang tidak mampu. Dalam konteks kehidupan masyarakat, negara mempunyai tugas yang sangat signifikan, sebuah tanggung jawab atas semua sisi kehidupan yang berbeda dan bertujuan untuk menciptakan kehidupan yang mulia. Untuk itu, Islam memberikan ketentuan/ aturan yang berhubungan dengan pajak, zakat adalah beban

${ }^{1}$ Gusfahmi, Pajak menurut Syariah, (Jakarta: Rajawali Press, 2007), ix.

${ }^{2}$ Minhaji, Teori Komprehensif Tentang Zakat dan Pajak, (Yogyakarta: Tiara Wacana Yogya, 2003), xiii. 
$42 \mid$ Dina Yustisi Yurista

pajak pertama yang harus dibayarkan seorang muslim dalam kehidupan mereka. ${ }^{3}$

Berdasarkan kondisi tersebut, maka pemasyarakatan ibadah zakat yang dituntunkan oleh Syariat Islam perlu ditingkatkan. Salah satu Ulama Besar Mesir yang sangat terkenal karena perhatiannya yang besar terhadap perkembangan sosial dan ekonomi Ummat Islam ialah Yusuf Qordhowi.

\section{Biografi Yusuf Qardhawi}

Yusuf al-Qardhawi lahir pada tanggal 9 September 1926, di Desa Safat Turab, Mesir bagian Barat, sebuah lingkungan masyarakat yang terdidik. Nama lengkap Yusuf Qardhawi adalah Yusuf ibn Abdullah al-Qardhawi. Dia berasal dari keluarga yang tekun beragama. Dalam usia dua tahun hidup tanpa bimbingan sang ayah, yang lebih dulu meninggal dunia. Ia menjadi anak yatim yang mulai saat itu diasuh oleh pamannya. ${ }^{4}$

Dengan perhatian yang cukup baik dan lingkungan keluarag yang tekun, teguh dan kuat beragama itu, Yusuf alQardhawi pada umur lima tahun teah memulai hafal Al-Qur'an. Dalam perkembangannya, belum sampai usia 10 tahun ia sudah mampu menghafal Al-Qur'an secara keeluruhan serta fasih bacaannya, karena pengetahuannya tentang tajwid yang sempurna dan merdu pula suaranya. ${ }^{5}$

Pendidikan selanjutnya diteruskan ke Ma'had Tanta, yang diselesaikan selama empat tahun, kemudian dilanjutkan pada tingkat menengah yang diselesaikan dalam waktu lima tahun. Dari sinilah al-Qardhawi melanjutkan pendidikan tingkat

${ }^{3}$ Abdul Sami Al-Misri, Pilar-pilar Ekonomi Islam, alih bahasa oleh Dimyauddin Djuwaini, (Yogyakarta: Pustaka Pelajar, 2006), 129.

4 Yusuf Qardhawi, Huda al-Islam: Fatawa al-Muasiroh, alih bahasa Abdurrahman Ali Bauzain (Surabaya: Risalah Gusti, 1989), 455.

5 Yusuf Al-Qardhawi, Pasang Surut Gerakan Islam, alih bahasa Fariq Uqbah dan Hartono (Jakarta: Medan Dakwah, 1987), 154.

ulul albab: Jurnal Studi dan Penelitian Hukum Islam 
Prinsip Keadilan dalam Kewajiban ... $\mid 43$

tingginya dengan memasuki universitas al-Azhar, Kairo untuk mengambil bidang studi agama pada fakultas Ushuluddin sampai mendapat syahadah aliyah (tahun 1952-1953), dengan predikat lulus terbaik. Kemudian pada tahun 1957 al-Qardhawi masuk pada $M a^{\prime}$ had al-Buhus wa ad-Dirat al-Arabiyah sehingga mendapatkan diploma tinggi di bidang bahasa dan sastra. ${ }^{6}$

Pada tahun 1956, Dr. Yusuf Qardhawi bekerja di bagian pengawasan bidang Agama pada kementrian Perwakafan di Mesir dengan aktifitas ceramah dan mengajar di masjid-masjid. Kemudian diangkat menjadi pemilik lembaga Al-Immah. Pada tahun 1959 dipindahkan ke bagian administrasi uum untuk Tsaqofah Islamiyah di Universitas Al-Azhar untuk mengawasi penerbitannya, dan bekerja dikantor seni pengelolaan dakwah dan bimbingan. Pada tahun 1961, beliau ditugaskan ke Qatar sebagai pemimpin Lembaga Pendidikan Agama tingkat menengah. Pahun 1973, didirikan Fakultas Tarbiyah yangmerupakan cikal bakal Universitas Qatar. Kemudian ia dipindahkan ke sana untuk mendirikan sekaligus memimpin bagian Dirasah Islamiyyah (Islamic studies). Pada tahun 1977, ia merintis dan mendirikan Fakultas Syari'ah dan Dirasah Islamiyyah di Universitas Qatar. Sebagaimana ia juga telah menjadi direktur Pusat Pengkajian Sunnah dan Sirah Nabawiyyah di Universitas Qatar, di samping posisinya sebagai dekan fakultas. ${ }^{7}$

Pemikiran al-Qardhawi dalam bidang agama dan politik banyak dipengaruhi oleh Hasan al-Banna, pendiri gerakan alIkhwan al-muslimun, al-Qardhawi juga tercatat sebagai salah satu seorang anggotanya. Salah satu pemikiran dan ajaran Hasan al-Banna yang tertulis dalam karya monumentalnya Risalat at-Ta'lim, diserap al-Qardhawi yang kemudian

${ }^{6} \mathrm{Ibid}, 155$.

7 Yusuf Al-Qardhawi, Pemikiran Dr. Yusuf al-Qardhawi Dalam Timbangan, alih bahasa M. Abdul Ghoffar, (Bogor: Pustaka Imam Asy-syafi'i, 2003), 8. 
$44 \mid$ Dina Yustisi Yurista

dijadikannya sebagai landasan utama dalam pemikiran hukumnya, yaitu ajaran kebebasan dari pengaruh ta'assub (fanatisme) terhadap mazhab.

Disamping Hasan al-Banna, al-Qardhawi juga pengagum Ibnu Taimiyah dan juga muridnya, Ibnu Qayyim. Meskipun demikian, bukan merupakan penghalang bagi Qarhawi untuk tidak sependapat dalam beberapa masalah dengan mereka. ${ }^{8}$

Sebagai seorang ulama yang membenci sikap taqlid dan fanatisme terhadap mazhab, al-Qardhawi membebaskan keterikatan dirinya terhadap sesuatu mazhab ketika menghadapi persoalan-persoalan. Al-Qardhawi sangat terbuka menerima pendapat-pendapat yang datang dari berbagai mazhab. Hal tersebut menurutnya bukanlah taqlid (mencampur adukkan) pendapat-pendapat seperti yang dikatakan orang, tetapi sekedar mengikuti petunjuk dari data yang diperoleh. Menurut al-Qardhawi seorang muhaqqin yang baik hanya boleh mengikuti dalil-dalil yang netral dan bersumber dari al-kitab dan as-sunah. ${ }^{9}$ Al-Qardhawi berandangan bahwa sudah saatnya sekarang ini untuk melakukan ijtihad insya'i, yaitu upaya melahirkan hukum yang sama sekali orisinil, upaya pemikiran yang belum pernah dihasilkan orang-orang terdahulu. ${ }^{10}$

Sebagai seorang cendikiawan, al-Qardhawi dangat produktif menulis untuk menyampaikan gagasan dan pemikirannya, baik yang berkaitan dengan hukum Islam maupun yang berkaitan dengan masalah sosial, ekonomi, dan budaya secara global. Hingga saat ini al-Qardhawi menghabiskan waktunya untuk menulis, mengarang bukubuku dan artikel, diantaranya adalah:

8 Ibid, 156.

${ }^{9}$ Yusuf Al-Qardhawi, Hukum Zakat, alih bahasa Salman Harun dkk, Cet. IV, (Bandung: Mizan, 1996), 18.

10 Yusuf Al-Qardhawi, Dasar-dasar Pemikiran Hukum Islam, alih bahasa Hasan Firdaus, (Jakarta: Pustaka Firdaus, 1987), 85.

ulul albab: Jurnal Studi dan Penelitian Hukum Islam 
a. Huda al-Islam, Fatawa al-Mu'asiroh

b. Al-halal wa al-Haram

c. Al-Ibadah Fi al-Islam

d. Iman wa Taqiyyah

e. An-nas wa al-Haq

f. Iman wa al-Hayat

g. Al-Waqt fi Hayat al-Muslm

h. As-Sahwah al-Islamiyyah Baina al-Juhd wa at-Tatarruf

i. Kaifa Nata'ammal ma'a as-Sunna an-Nabawiyyah Ma'alim wa Dawabit

j. Al-Kahsais al-Ammah li al-Islam

\section{Definisi Pajak}

Menurut Prof. Dr. Rochmat Soemitro, pajak adalah peralihan kekayaan dari sektor swasta ke sektor publik berdasarkan undang-undang yang dapat dipaksakan dengan tidak mendapat imbalan yang secara langsung dapat ditunjukkan, yang digunakan untuk membiayai pengeluaran umum dan yang digunakan sebagai alat pendorong, penghambat atau pencegah, untuk mencapai tujuan yang ada di luar bidang keuangan. ${ }^{11}$

Menurut Prof. Dr. P.J.A. Adriani, pajak adalah iuran kepada negara (yang dapat dipaksakan) yang terutang oleh yang wajib membayarnya menurut peraturan-peratuan, dengan tidak mendapat prestasi kembali, yang langsung dapat ditunjuk, dan yang gunanya adalah untuk membiayai pengeluaran umum berhubung dengan tugas negara untuk menyelenggarakan pemerintahan. ${ }^{12}$

${ }^{11}$ Rahmat Soemitro, Pengantar Singkat Hukum Pajak, (Refika Aditama, Cet ke-2, 1988), 12.

12 Santoso Brotodiharjo, Pengantar Ilmu Hukum Pajak, (Bandung: PT. Eresco, 1982), 2. 
$46 \mid$ Dina Yustisi Yurista

Secara etimologi, pajak dalam bahasa Arab disebut ضرب يضرب ضربا dengan istilah dharibah. ${ }^{13}$ yang berasal dari kata dasar (dharaba, yadhribu, dharban ) yang artina mewajibkan, menetapkan, menentukan, memukul, menerangkan atau membebankan, dan lain-lain. ${ }^{14}$

Secara bahasa maupun tradisi, dharibah dalam penggunaannya memang mempunyai banyak arti, namun para ulama dominan memakai ungkapan dharibah untuk menyebut harta yang dipungut sbagai kewajiban. Hal ini tampak jelas dalam ungkapan bahwa jizyah dan kharaj dipungut secara dharibah, yakni secara wajib. Bahkan sebagian ulama menyebut kharaj merupakan dharibah. Jadi, dharibah adalah harta yang dipungut secara wajib oleh negara untuk selain jizyah dan kharaj, sekalipun keduanya bisa dikategorikan dharibah. ${ }^{15}$

Gazy Inayah berpendapat, pajak adalah kewajiban untuk membayar tunai yang ditentukan oleh pemerintah atau pejabat berwenang yang bersifat mengikat tanpa adanya imbalan tertentu. Ketentuan pemerintah ini sesuai dengan kemampuan si pemilik harta dan dialokasikan untuk mencukupi kebutuhan pangan secara umum dan untuk memenuhi tuntutan politik keuangan bagi pemerintah. ${ }^{16}$

Yusuf Qardhawi berpendapat, pajak adalah kewajiban yang ditetapkan terhadap terhadap Wajib Pajak, yang harus disetorkan kepada negara sesuai dengan ketentuan, tanpa mendapat prestasi kembali dari negara, dan hasilnya untuk membiayai pengeluaran-pengeluaran umum di satu pihak dan

${ }^{13}$ Gazy Inayah, Op.cit, 24; Yusuf Al-Qordhowi, Fiqih Az-zakah ..., 1001.

14 A. W. Munawwir, Kamus Al-Munawwir, (Surabaya: Pustaka Progessif, 2002), 815.

15 Gusfahmi, Pajak menurut ..., 28.

16 Gazy Inayah, Al-Iqtishod al-Islami az-Zakah wa ad-Dharibah, Dirasah Muqaranah, 1995, Edisi Terj. Oleh Zainudin Adnan dan Nailul Falah, Teori Komprehensif Tentang Zakat dan Pajak, (Yogyakarta: Tiara Wacana Yogya, 2003), 24.

ulul albab: Jurnal Studi dan Penelitian Hukum Islam 
untuk merealisasi sebagai tujuan ekonomi, sosial, politik, dan tujuan-tujuan lain yang ingin dicapai oleh negara. ${ }^{17}$

\section{Definisi Zakat}

Kata zakat berarti menumbuhkan, memurnikan (mensucikan), memperbaiki, yang berarti pembersihan diri yang didapatkan setelah pelaksanaan kewajiban membayar zakat. Seseorang dikatakan berhati suci dan mulia apabila ia tidak kikir dan tidak terlalu mencita harta (untuk kepentingan dirinya sendiri). Harta merupakan sesuatu yang disayangi orang dan setiap orang mencintai hartanya seta sumber-sumber kekayaan lain. Akan tetapi, orang yang membelanjakan hartanya untuk orang lain akan memperoleh kemuliaan dan kesucian. Inilah pertumbuhan dan kemuliaan yang sebenarnya yang ia peroleh dengan membayar. ${ }^{18}$

Aspek zakat ini dijelaskan dalam Al-Qur'an:

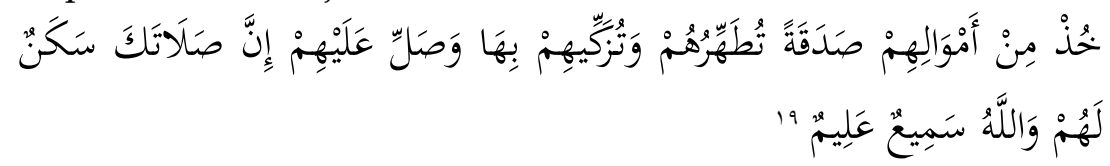

Artinya : "Ambillah zakat dari sebagian harta mereka, dengan zakat itu kamu membersihkan dan mensucikan mereka."

Zakat mengandung arti kemenangan, seperti firman Allah SWT:

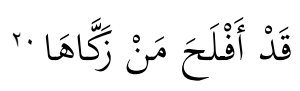

17 Yusuf Qardhawi, Fiqih Zakah, Muassasah ar-Risalah, (Beirut Libanon: Cet.II, 1973) Terj oleh Salman harus, Didin Hafidhuddin, dan Hasanuddin, Hukum Zakah, (Jakarta: PT Pustaka Litera AntarNusa, Cet.12, 2011), 998.

${ }^{18}$ Afzalur Rahman, Doktrin Ekonomi Islam, (Yogyakarta: Dana Bhakti Prima Yasa, 2002), 235.

${ }^{19}$ At-Taubah: 103.

${ }^{20}$ As-Syams: 9. 
48|Dina Yustisi Yurista

Artinya: "Sesungguhnya beruntunglah orang yang membayar zakat itu".

Zakat adalah kewajiban yang bersifat mengikat, artinya membayar zakat bagi seorang muslim mukallaf adalah suatu keharusan. Sifat wajibnya itu berdasarkan keberadaannya sebagai kewajiban terhadap harta ilahiyah dan ibadah yang berkaitan dengan harta itu diwajibkan. Kewajiban zakat ini seperti pajak dalam hal tidak adanya hak bagi masyarakat untuk menolak atau menerimanya sebagaimana sebelumnya atau tidak ada hak untuk menghindar dari membayar zakat. ${ }^{21}$

Zakat merupakan salah satu ciri dari sistem ekonomi Islam, karena zakat merupakan salah sau implementasi azas keadilan dalam sistem Ekonomi Islam. ${ }^{22}$ Menurut M.A.Mannan zakat mempunyai enam prinsip yaitu ${ }^{23}$ :

1) Prinsip keyakinan keagamaan, yaitu bahwa orang yang membayar zakat merupakan salah satu manifestasi dari keyakinan agamanya

2) Prinsip pemerataan dan keadilan, merupakantujuan sosial zakat yaitu membagi kekayaan yang diberikan Allah lebih merata dan adil kepada manusia

3) Prinsip Produktifitas, menekankan bahwa zakat memang harus dibayar karena milik tertentu telah menghasilkan produk tertentu setelah lewat jangka waktu terentu

4) Prinsip Nalar, sangat rasional bahwa zakat harat yang menghasilkan itu harus dikeluarkan

5) Prinsip Kebebasan, zakat hanya dibayar oleh orang yang bebas

6) Prinsip Etika dan Kewajaran, yaitu zakat tidak dipungut secara semena-mena.

${ }^{21}$ Minhaji, Teori Komprehensif ..., 4.

22 M.A.Mannan, Islamic Economics; Theory and Practice, Terj M. Nastangin, (Yogyakarta: Dhana Bhakti Wakaf, 1997), 256.

${ }^{23}$ Ibid, 257.

ulul albab: Jurnal Studi dan Penelitian Hukum Islam 
\begin{tabular}{l|l} 
Prinsip Keadilan dalam Kewajiban ... & 49
\end{tabular}

\section{Perbedaan antara Pajak dan Zakat}

Zakat dan pajak, meski keduanya sama-sama merupakan kewajiban dalam bidang harta, berdasarkan ketetapan pemerintah, sifatnya memaksa, tanpa imbalan serta sesuai dengan beban yang dipikul individu, namun keduanya mempunyai falsafah yang khusus dan keduanya berbeda sifat dan asanya, menurut Yusuf Qordhawi ada 7 perbedaan antara pajak dan zakat, antara lain adalah ${ }^{24}$ :

1) Nama dan etikatnya

Kata zakat menurut bahasa, berarti suci, tumbuh, dan berkah. Syariat Islam memilih kata zakat untuk mengungkapkan arti dari bagian harta yang wajb dikeluarkan untuk fakir miskin dan para mustahik lainnya. Sesuai dengan firman Allah SWT:

"Ambillah sedekah dari bagian harta mereka, dengan sedekah itu kamu membersihkan dan mensucikan" 25

Berbeda dengan pajak, sebab pajak diambil dari kata dharaba, yang artinya utag, pajak tanah, atau upeti dan sebagainya. Yaitu esuatu yang mesti dibayar, sesuatu yang menjadi beban. Seperti dalam Al-Qur'an:

"Dan ditimpakan atas mereka kehinaan dan kemiskinan" 26

2) Hakikat dan Tujuannya

Zakat adalah ibadah yang diwajibkan kepada orang Islam, sebagai tanda syukur kepada Allah SWT dan mendekatkan diri kepadaNya. Sedangkan pajak adalah kewajiban dari negara semata-mata yang tidak ada hubungannya dengan makna ibadat dan pendekatan diri.

3) Batas Nisab dan Ketentuannya

\footnotetext{
${ }^{24}$ Yusuf Qardhawi, Fiqih Zakah, ..., 1000.

${ }^{25}$ At-Taubah: 103.

${ }^{26}$ Al-Baqarah:61.
} 
Dalam zakat, batas nisab serta ketentuannya telah ditentukan oleh Allah. Seorang pun tidak boleh menambah atau mengurangi. Berbeda engan pajak yang bergantung pada kebijaksanaan dan kekuatan pemerintah mengenai objek, prosentase, harga dan keentuannya.

4) Kelestarian dan Kelangsungan

Zakat adalah kewajiban yang bersifat tetap dan terus menerus yang mana tidak dapat dihapskan kewajiban tersebut oleh siapa pun. Adapun pajak, tidak memiliki sifat tetap dan terus menerus dan pemerintah dapat menambah atau menguranti atas dasar pertimbangan para cendikia.

5) Pengeluaran

Zakat mempunyai sasaran khusu yang ditetapkan oleh Allah SWT dalam Qur'an dan dijelaskan oleh Rasulullah S.A.W dengan perkataan dan perbuatannya. Sasaran zakat adalah kemanusiaan dan keislaman. Adapaun pajak dikeluarkan untuk membiayai pengeluaranpengeluaran umum negara, sebagaimana ditetapkan pengaturannya oleh penguasa.

6) Hubungannya dengan penguasa

Pajak selalu berhubungan antara waib pajak dengan pemerintah yang berkuasa, Adapun zakat adalah hubungan antara penzakat dengan Tuhannya.

7) Maksud dan Tujuan

Pajak adalah kewajiban murni masyarakat dan beban duniawi, sedangkan zakat adalah sebaliknya, yaitu kewajiban syariat dan beban ukhrawi. ${ }^{27}$ Zakat memiliki tujuan spiritual dan moral yang lebih tinggi dari pajak.

${ }^{27}$ Gazy Inayah, Al-Iqtishod al-Islami ..., 24. 


\section{Prinsip keadilan antara Pajak dan Zakat menurut Yusuf Qardhawi}

Keadilan beban keuangan dalam zakat itu dapat menyelamatkan sistem ekonomi Islam dalam hal pembebanan. Keadilan zakat yang hakiki menghendaki kesesuaian antara beban dan kemampuan. Suatu saat zakat akn mampu melestarikan kemampuan beban dan situasi kehidupan masyarakat. ${ }^{28}$

Kaidah-kaidah keadilan pajak mencakup semua orang yang dibebani pajak untuk membantu aparat pajak dengan cara tidak menghindari pajak. Keadilan pajak menghendaki seseorang tidak lari dari membayar pajak dan tidak boleh melebihi batas-batas yang sudah ditentukan dalam perpajakn serta tidak membebani masyarakat. ${ }^{29}$

Menurut Yusuf Qardawi, Prinsip-prinsip keadilan antara pajak dan zakat meliputi 4 prinsip, yaitu ${ }^{30}$ :

Pertama adalah prinsip keadilan, yang meliputi

1) Sama rata dalam kewajiban zakat dan pajak

Setiap muslim yang mempunyai satu nisab zakat adalah wajib zakat tana memandang bangsa, warna kulit, keturunan, atau kedudukan dalam masyarakat, laki-laki, perempuan, pemerintah, yang diperintah, pemimpin agama, pemimpin negara, semua sama. Dalam pajak terdapat asas kesamaan, yaotu bahwa seseorang dalam keadaan yang sama hendaknya dikenakan pajak yang sama. Dalam asas kesamaan equality (asas persamaan) tidak boleh suatu negara mengadakan diskriminasi di antara wajib pajak. ${ }^{31}$

2) Membebakan harta (zakatdan pajak) yang kurang senisab atau batas yang telah ditentukan

${ }^{28} \mathrm{Ibid}, 48$.

${ }^{29} \mathrm{Ibid}, 193$.

${ }^{30}$ Yusuf Qardhawi, Fiqih Zakah..., 1039.

${ }^{31}$ Bohari, Pengantar Hukum Zakat, cet V, (Jakarta: Rajawali Pers, 2004), 41. 
Untuk tercapainya suatu keadilan, Islam dalam kewajiban zakat membebaskan harta yang sedikit dari kewajiban zakat. Zakat tidak diwajibkan kecuali bagi harta yang mencapai satu nisab. Hal ini dimaksudkan agar pemungutan zakat dari kelebihan akan mudah bagi jiwa dan tidak berat bagi tabiat manusia. ${ }^{32}$ Begitu pula dengan asas perpajakan yang membebaskan pajak bagi yang pendapatannya di bawah basic need.

3) Larangan berzakat dan pajak dua kali

Keadilan pajak keuangan Islam menetapkan prinsip penyatuan aplikasi zakat dan tidak ada zakat ganda untuk mencegah pemaksaan bagi pemilik harta, adanya unsur kedzaliman, penghalang harta, dan pemeliharaan kemampuan beban harta. ${ }^{33} \mathrm{Di}$ antara pelaksanaan prinsip yang paling tampak adalah undang-undang yang diuraikan Rasulullah SAW. Dalam sabdanya:

$$
\text { لا ثنى في الصدقة؛r }
$$

Berdasarkan hadits tersebut ibnu Qudamah menetapkan bahwa tidak boleh mewajibkan zakat dua kali dalam setahun dengan satu sebab.

4) Besar zakat dan pajak sebanding dengan tenaga yang dikeluarkan

Semakin mudah memperoleh semakin besar zakatnya, seperti halnya zakat pertanian ada yang $10 \%$ dan $5 \%$.

5) Memperhatikan kondisi dalam pembayaran pajak dan zakat

Dengan memperhatikan besarnya pendapatan, beban keluarga, hutang-hutang yang dimiliki, dipngut dari pendapatan bersih. Keadilan pajak mempertimbangkan beban kemampuan pembayar pajak, sebab pajak

\footnotetext{
32 Yusuf Qardhawi, Fiqih Zakah ..., 1040.

${ }^{33}$ Gazy Inayah, Al-Iqtishod al-Islami ..., 190.

${ }^{34}$ Abi' Abid al-Qasim ibn Salam, al-Amwal, (Beirut: Dar al-Fikr, 1988), 1041.
} 
Prinsip Keadilan dalam Kewajiban ... $\mid 53$

ditentukan tidak berdasarkan nisab, sedangkan zakat diambil karena ada unsur kelebihan kebutuhan pemilik harta dan kebutuhan keluarganya. ${ }^{35}$

6) Keadilan dalam praktek pajak dan zakat.

Islam memberikan perhatian isimewa dan hati-hati terhadap pelaksana pemungut zakat (amil), yaitu dengan persyaratan yang tinggi untk menjadi amil, dan posisi yang mulia bagi mereka. Seperti Hadts: "Orang yang bekerja memungut sedekah dengan benar adalah seperti orang yang berperang di jalan Allah" (Hadits Sahahih)

Kedua adalah prinsip kepastian. Kepastian pajak ditetapkan kepada para subjek pajak dengan cara yang pasti, tidak tersembunyi, baik mengenai waktu, tata cara, jumlah setoran, harus terang dan jelas bagi subjek pajak dan bagi siapa pun. Kepastian itu sangat era hubungannya dengan kestabilan pajak. Apabila subjek pajak telah biasa menyerahkan pembayaran pajak tertentu, maka ia pun merasakan adanya kepastian dalam persoalannya.

Stabilnya pergaulan hidup dan hubungan manusia akan mendorong ke arah berkembangnya kemajuan ekonomi. Keadaannya dapat disamakan dengan pajak. Banyaknya perubahan mengenai aturan-aturan perpajakn tidak diragukan lagi akan mengakibatkan hilangnya kepercayaan dan timbulnya keraguan di kalangan masyarakat. ${ }^{36}$ Kaedah kepastian dalam zakat terlihat karena Allah SWT telah mewajibkan dalam kitabNya dan telah menentukan kadarnya melalui rasulNya.

Prinsip ketiga adalah prinsip kelayakan. Pajak seharusnya dilakukan ketika wajib pajak itu dalam keadaan senang. ${ }^{37}$ Misalnya: pmungutan pajak bumi dan bangunan terhadap para petani, sebaiknya dipungut pada saat mereka

${ }^{35}$ Gazy Inayah, Al-Iqtishod al-Islami ..., 50.

${ }^{36}$ Dikutip dari Mubadi Ilmil-Mahiah al-Ammah (Prinsip-prinsip Ilmu Keuangan Umum), Dr. Muhammad fuad Ibrahim, 267.

${ }^{37}$ Bohari, Pengantar Hukum ...., 42. 
$54 \mid$ Dina Yustisi Yurista

memperoleh uang yaitu pada saat panen. Prinsip ini menekankan untuk menjaga perasaan wajib pajak, dan berlaku sopan terhadap mereka. Hal ini untuk menarik simpatik sehingga mereka dengan sukarela akan menyerahkan pajak itu tanpa ada rasa ragu dan terpaksa karna perlakuan yang kurang baik.

Dalam memungut zakat tidak diperbolehkan memungut harta yang terbaik tapi diperintahkan untuk memungut harta yang pertengahan. Pada prinsip ini menghendaki perolehan zakat untuk melestarikan harta dari muzakki, untuk itu tidak boleh mengambil harta yang terbaik juga tidak boleh mengambil harta yang terjelek, tetapi harta yang dikeluarkan adalah harta yang tengah-tengah. ${ }^{38}$

Prinsip keempat dalam prinsip keadilan antara pajak dan zakat adalah prinsip ekonomis.Maksud prinsip ekonomis pajak adalah ekonomis dalam biaya pemungutan pajak, dan menjauhi berbagi pemborosan. Biaya yang dikeluarkan oleh negara untuk biaya gaji pegawai pajak, biaya administrasi dan peralatan, serta biaya transportasi harus dikeluarkan oleh para wajib pajak ke tempat kantor penyetoran pajak dan harus bersifat ekonomis. Asas ini menekankan bahwa biaya pemungutan pajak tidak boleh lebih dari hasil yang akan diterima. ${ }^{39}$

Islam memerintahkkan untuk berlaku sederhana dan ekonomis, dan melarang pemborosan serta berlebih-lebihan. Apabila dikaitkan dengan zakat, maka hukum Islam sangat kompeten untuk tidak berbuat aniaya dalam penarikan zakat, baik dari para amilnya atau dari wajib zakat serta melarang menerima hadiah sebagai penarik zakat.

${ }^{38}$ Gazy Inayah, Al-Iqtishod al-Islami ..., 56.

${ }^{39}$ Bohari, Pengantar Hukum ..., 42.

ulul albab: Jurnal Studi dan Penelitian Hukum Islam 
Prinsip Keadilan dalam Kewajiban ... $\mid 55$

\section{Kesimpulan}

Yusuf Qardhawi berpendapat, pajak adalah kewajiban yang ditetapkan terhadap terhadap Wajib Pajak, yang harus disetorkan kepada negara sesuai dengan ketentuan, tanpa mendapat prestasi kembali dari negara, dan hasilnya untuk membiayai pengeluaran-pengeluaran umum di satu pihak dan untuk merealisasi sebagai tujuan ekonomi, sosial, politik, dan tujuan-tujuan lain yang ingin dicapai oleh negara

Kata zakat berarti menumbuhkan, memurnikan (mensucikan), memperbaiki, yang berarti pembersihan diri yang didapatkan setelah pelaksanaan kewajiban membayar zakat. Zakat adalah kewajiban yang bersifat mengikat, artinya membayar zakat bagi seorang muslim mukallaf adalah suatu keharusan.

Zakat dan pajak, meski keduanya sama-sama merupakan kewajiban dalam bidang harta, namun keduanya memiliki perbedaan yang mendasar, Menurut Yusuf Qordhawi perbedaan diantara keduanya, meliputi: nama dan etikatnya, hakikat dan tujuannya, batas nisab dan ketentuannya, kelestarian dan kelangsungan, pengeluaran, hubungannya dengan penguasa, dan maksud dan tujuan.

Yusuf Qardhawi berpendapat bahwa prinsip keadilan antara pajak dan zakat mencakup empat hal, yaitu: pertama prinsip keadilan yang meliputi Sama rata dalam kewajiban zakat dan pajak, membebakan harta (zakatdan pajak) yang kurang senisab atau batas yang telah ditentukan, larangan berzakat dan pajak dua kali, besar zakat dan pajak sebanding dengan tenaga yang dikeluarkan, memperhatikan kondisi dalam pembayaran pajak dan zakat, serta keadilan dalam praktek pajak dan zakat. Kedua prinsip kepatian, ketiga prinsip kelayakan, dan yang keempat prinsip ekonomis. 
$56 \mid$ Dina Yustisi Yurista

\section{Daftar Pustaka}

Al-Qur'an Karim

A. W., Munawwir. 2002. Kamus Al-Munawwir. Surabaya: Pustaka Progessif.

Afzalur, Rahman. 2002. Doktrin Ekonomi Islam. Yogyakarta: Dana Bhakti Prima Yasa.

Al-Misri, Sami Abdul. 2006. Pilar-pilar Ekonomi Islam, alih bahasa Dimyauddin Djuwaini. Yogyakarta: Pustaka Pelajar.

Al-Qardhawi, Yusuf. 1973. Fiqih Zakah,. Beirut Libanon:

Muassasah ar-Risalah, Cet.II. Diterjemahkan oleh Salman

Harun, Didin Hafidhuddin, dan Hasanuddin. 2011.

Hukum Zakah. Jakarta: PT Pustaka Litera AntarNusa, Cet.12.

Al-Qardhawi, Yusuf. 1987. Dasar-dasar Pemikiran Hukum Islam, alih bahasa Hasan Firdaus. Jakarta: Pustaka Firdaus.

Al-Qardhawi, Yusuf. 1987. Pasang Surut Gerakan Islam, alih bahasa Fariq Uqbah dan Hartono. Jakarta: Medan Dakwah.

Al-Qardhawi, Yusuf. 1989. Huda al-Islam: Fatawa al-Muasiroh. alih bahasa Abdurrahman Ali Bauzain. Surabaya: Risalah Gusti.

Al-Qardhawi, Yusuf. 2003. Pemikiran Dr. Yusuf al-Qardhawi

Dalam Timbangan, alih bahasa M. Abdul Ghoffar. Bogor:

Pustaka Imam Asy-syafi'i.

Bohari. 2004. Pengantar Hukum Zakat. Jakarta: Rajawali Pers, Cet. V.

Gazy, Inayah. 1995. Al-Iqtishod al-Islami az-Zakah wa ad-Dharibah.

Dirasah Muqaranah. Diterjemahkan oleh Zainudin Adnan dan Nailul Falah. 2003. Teori Komprehensif Tentang Zakat dan Pajak. Yogyakarta: Tiara Wacana Yogya.

Gusfahmi. 2007. Pajak menurut Syariah. Jakarta: Rajawali Press. Ibn Salam, Abi' Abid al-Qasim ibn Salam. 1998. al-Amwal. Beirut: Dar al-Fikr. 
Prinsip Keadilan dalam Kewajiban ... $\mid 57$

Mannan. 1997. Islamic Economics; Theory and Practice, alih bahasa M. Nastangin. Yogyakarta: Dhana Bhakti Wakaf.

Minhaji. 2003. Teori Komprehensif Tentang Zakat dan Pajak. Yogyakarta: Tiara Wacana Yogya.

Rahmat, Soemitro. 1998. Pengantar Singkat Hukum Pajak. Refika Aditama, Cet ke-2.

Santoso, Brotodiharjo. 1982. Pengantar Ilmu Hukum Pajak. Bandung: PT. Eresco. 